\title{
Impact of phenolic composition on hepatoprotective and antioxidant effects of four desert medicinal plants
}

\author{
Naglaa Gamil Shehab ${ }^{1 *}$,Eman Abu-Gharbieh ${ }^{2}$ and Fatehia A. Bayoumi ${ }^{3}$
}

\begin{abstract}
Background: Flavonoids and other polyphenols play a protective role in liver diseases and possess a high antioxidant capacity.

Objective: To compare and evaluate the antioxidant and hepatotoprotective activities of 4 deserts plants, Fagonia indica Burm. f., Calotropis procera R.Br., Zygophylum hamiense Schweinf. and Salsola imbricata Forssk. in correlation to their composition especially their phenolic content.

Methods: The influence of extracting solvent on total phenolic and flavonoidal contents was assessed spectrophotometrically. The flavonoid and other polyphenolic components of the methanol extracts were analyzed by RP-HPLC. DPPH radical scavenging potential of the different extracts was estimated. The hepatoprotective and antioxidant activities of the extracts against $\mathrm{CCl}_{4}$-induced hepatotoxicity in mice were evaluated.

Results: The flavonol quercitrin and rosmarinic acid were major in the F. indica, C. procera and S. imbricata samples, while rutin prevailed in that of $Z$. hamiense. The ethanolic and methanolic extracts showed noticeable DPPH radical-scavenging activity as compared to ascorbic acid. Assessment of liver enzymes revealed that oral administration of the extracts did not show any evidence of hepatotoxicity. Moreover, protection against $\mathrm{CCl}_{4}$-induced liver damage was evident upon administration of three plants extracts namely, F. indica, C. procera and S. imbricata.

Conclusion: Overall, hepatotoxicity induced by $\mathrm{CCl}_{4}$ was effectively prevented by the three plants extracts through scavenging of free radicals and by boosting the antioxidant capacity of the liver. The protective effect of the plants could be attributed to their high quercitrin and rosmarinic acid contents.
\end{abstract}

Keywords: Antioxidant, Flavonoids, Hepatoprotective, Phenolic acids

\section{Background}

Human beings are daily exposed to various compounds that can cause serious diseases either per se or through their metabolic activation to highly reactive substances such as reactive oxygen species (ROS). Free radical induced lipid peroxidation is regarded as one of the main causes of cell membrane damage leading to various pathological conditions [1,2]. Liver disorders are considered among the major world health problems [3]. Despite their prevalence, morbidity and mortality rates, their current medical management is still considered inadequate. Until

\footnotetext{
* Correspondence: Naglaa_shehab@hotmail.com

'Department of Pharmacognosy, Faculty of Pharmacy, Cairo University, Cairo, Egypt

Full list of author information is available at the end of the article
}

now, no therapy shows complete success in preventing the disease progression [4]. Besides, the newly developed drugs used in management of chronic liver diseases are usually associated with various, and sometime intolerable, side effects [5]. Consequently, medicinal plants, especially those with traditional use, have always been considered as a rich source of new effective drugs which could help in ameliorating liver conditions.

Among plant metabolites, phenolics are reputed to play a noticeable protective role against several health disorders [6]. Phenolics possess various biological activities, for instance, antiulcer, anti-inflammatory [7], antidiabetic [8], antioxidant, cytotoxic and antitumor $[9,10]$.

Fagonia indica Burm. f. (Mushikka or white spine) (Zygophyllaceae) is a widely distributed plant in the 
deserts of Asia and Africa. It has been reported as medicinal herb in the scientific literature. In an earlier study, the main author reported that the plant could be considered as safe and that it contained a variety of bioactive flavonoids, sterols and triterpenoids; its alcoholic extract was found to exhibit antitumor, antimicrobial and analgesic activities [11]. Furthermore, the methanolic extract of an Indian sample of the plant was proven to exert a hepatoprotective effect in rats; however, the mechanism of action has not yet been explored [12].

Calotropis procera R. Br. (Asclepiadaceae), known as Giant milkweed and locally called Al-ashkhar [13], has been used for treating various diseases like rheumatism, filariasis and skin disorders [14] and its leaf to treat jaundice [15]. The flowers extract have been used for treating spleen, liver and abdomen diseases [16]. Additionally, various extracts of its different parts showed antibacterial and in-vitro and in-vivo antioxidant activities [17-20]. Earlier phytochemical investigation of $C$. procera revealed the presence of cardenolides, flavonoids, steroids and saponins [21, 22]. The composition of the volatiles, lipoids and flavonoids of its flowers were previously investigated by the author [23].

Zygophyllum species (Family Zygophyllaceae) are used as anthelmintic and for management of diabetes mellitus $[24,25]$. The aqueous extract of Zygophyllum album showed in vivo antihyperglycemic, antioxidant and antihyperlipidemic effects [26] as well in-vitro and in-vivo antioxidant properties and phenolic contents of Zygophyllum species were investigated [27-29]. Zygophyllum hamiense Schweinf. spreads largely along the Arabian Gulf area and grows on salt accumulated land. The dead trees are commonly used as firewood and the sprouts as camel food [30]. Yet, there are no available reports regarding either the composition or biological activities of the Zygophyllum hamiense Schweinf.

Genus Salsola (Family Chenopodiaceae or Amaranthaceae) exhibited significant in-vitro antioxidant activities [31-33]. Flavonoid and other phenolic compounds from different species of Salsola have been reported. In addition, triterpenes with significant antioxidant activity were isolated [34, 35]. Salsola imbricata Forssk. (Arabic names: Harm), is a shrub wild growing in Middle East deserts; it is distributed throughout Central and Southwest Asia, North Africa, and Mediterranean countries [36, 37]. Previous phytochemical investigations and biological study of the plant were limited. Two triterpenoidal saponin glycosides were isolated and identified from the roots of the Egyptian plant [38]. The phenolic profile of the alcoholic extract of the plant was analyzed and its contraceptive effect in male albino rats previously evaluated by the authors [39].

The selected plants are growing and existing in the deserts. The deserts plants almost contain variety of secondary metabolites like flavonoids and phenolic acids to protect themselves from herbivores. Thus it was valuable and interesting to perform a comparative study on some selected desert plants from different genus, Fagonia indica Burm. f., Calotropis procera R.Br., Zygophylum hamiense Schweinf. and Salsola imbricata Forssk., and to correlate their biological activities such antioxidant and hepatotoprotective to their phenolic composition.

\section{Methods}

\section{Chemicals and drugs}

Methanol, ethanol, acetone and ethyl acetate were purchased from Fisher Scientifics (UK) \& Scharlam. Carbon tetrachloride $\left(\mathrm{CCl}_{4}\right)$, 2,2-diphenyl-1-picrylhydrazyl (DPPH), sodium carboxymethylcellulose (CMC), Biochemical kits for determination of glutathione peroxidase (GPx), superoxide dismutase (SOD), Catalase (CAT), Thiobarbituric acid reactive substances (TBARS) were purchased from Sigma Chemical Co. (St. Louis, MO, USA) and Folin-Ciocalteu reagent was obtained from Merck (Darmstadt, Germany). All other chemicals were of analytical grade.

\section{Plants material}

Whole plants of Fagonia indica Burm. f., Zygophylum hamiense Schweinf., Salsola imbricata Forssk. and leaves of Calotropis procera R. Br. were collected during September 2012 from Muhaisnah desert, Dubai, UAE. The samples were kindly identified and authenticated by Prof. Hassnaa Ahmed Hosny, Department of Botany, Faculty of Science, Cairo University, Egypt. Voucher specimens were kept at the Herbarium of the Pharmacognosy Department, Faculty of Pharmacy, Cairo University. Samples, air-dried in shade, were powdered and preserved for further study.

\section{Experimental animals Acute toxicity}

The acute toxicity studies of both $F$. indica and $S$. imbricata have been previously reported $[11,39]$. Male albino mice weighing $20-25$ g (10 per group) were used to estimate the acute toxicity of the other two plants viz., Z. hamiense and $C$. procera. $\mathrm{LD}_{50}$ was estimated using $50 \%$ death within $72 \mathrm{~h}$ following oral administration of the extracts at different doses $(250,500,1000,2500$ and $5000 \mathrm{mg} / \mathrm{kg})$. The number of animals, which died during this interval, was expressed as a percentile, and the $\mathrm{LD}_{50}$ determined by probit test using a death percent versus doses' $\log$ [40].

\section{Treatment protocol}

Eighty four healthy male albino mice of weights ranging from 30-35 g were used. Animals were kept under the same standard hygienic conditions (temperature $22.0 \pm 2.0{ }^{\circ} \mathrm{C}$, relative humidity 50-60\%, with $12 \mathrm{~h}$ day/night lighting cycle), fed with well-balanced normal diet and water supplied ad libitum. They were left for a period of one week for accommodation before performing the experiments. All animals' 
investigations were performed in accordance with the ethical standards for the proper care and use of laboratory animals and upon approval of the Research Ethical Committee of the Dubai Pharmacy College, Dubai, United Arab Emirates.

\section{Plants extracts}

The four air-dried powdered plants materials (500 g, each) were exhaustively extracted by cold maceration in $70 \%$ ethanol (3 L X 2). The solvents were evaporated under reduced pressure at $50{ }^{\circ} \mathrm{C}$. The residual weights for $F$. indica, C. procera, Z. hamiense and S. imbricata amounted to 80.0, 44.5, 28.0 and $20.0 \mathrm{~g}$, respectively. These dried extractives were saved and used for biological evaluation.

\section{Standardization of the plants extracts Colorimetric monitoring of phenolic content in different extracting solvents}

Solvents of different polarities, namely: $70 \%$ ethanol, methanol, acetone and ethyl acetate were individually used for extraction of the air-dried powdered plant materials (100 g, each).

The efficiency of the extracting solvent was monitored by colorimetric estimation of total phenolic and flavonoid contents using a spectrophotometer (UV-1700 Pharma Spec, Shimadzu, Japan). All experiments were carried out in triplicate.

The total phenolic contents were determined by using Folin-Ciocalteu reagent as described by Singleton and Rossi [41] and modified by Oktay et al. [42]. Results were expressed as $\mathrm{mg} / \mathrm{g}$ gallic acid equivalent, calculated on dry weight of plant material; serial dilutions of gallic acid $(10,20,30,40$, and $50 \mu \mathrm{g} / \mathrm{mL})$ were used for establishment of the calibration curve. Aliquots $(1 \mathrm{~mL}$, each) of tested samples and standard were, separately, added to a volumetric flask containing $9 \mathrm{~mL}$ of water followed by addition of $1 \mathrm{~mL}$ of Folin-Ciocalteu reagent and the reaction mixture was carefully blended by vortex. After $5 \mathrm{~min}, 10 \mathrm{~mL}$ of $7 \%$ sodium carbonate was added to the mixture which was further incubated for $90 \mathrm{~min}$, at room temperature. Finally, the absorbance was determined at $750 \mathrm{~nm}$ against the reagent blank.

The total flavonoid content of the prepared extracts was measured, spectrophotometrically, by the aluminum chloride method, quercetin being used as standard, by adopting the procedure described by Dewanto et al. [43]. The plants extracts $(0.1 \mathrm{~mL}$ each) were added to $0.3 \mathrm{~mL}$ distilled water followed by $5 \% \mathrm{NaNO}_{2}(0.03 \mathrm{~mL})$ and the reaction mixture was left for $5 \mathrm{~min}$, at $25{ }^{\circ} \mathrm{C}$. Aluminium chloride $(0.03 \mathrm{~mL}, 10 \%)$ was then added and the mixture left for another $5 \mathrm{~min}$, then treated with $0.2 \mathrm{~mL}$ of $1 \mathrm{mM} \mathrm{NaOH}$, and finally diluted to $1 \mathrm{~mL}$ with water and the absorbance of the yellow colour produced read at $510 \mathrm{~nm}$.

\section{HPLC analysis of phenolics}

The phenolic composition of the methanolic extract of $S$. imbricata was previously analysed by the authors [39]. Methanolic extracts of the other three plants (F. indica, $C$. procera and $Z$. hamiense) were investigated in aliquots of $1 \mathrm{~g}$ each via RP-HPLC on a Hewlett Packard HPLC System (HP 1050HPLCDADw/Data System). Analyses were carried out at operating conditions suitable for detection of either phenolic acids or flavonoids [44, 45]. For determination of phenolic acids, the apparatus was equipped with an Alltima C18 column (particle size $5 \mathrm{~mm}, 150 \times 4.6 \mathrm{~mm}$ ) and Alltima C18 guard column (5 mm) (Alltech, USA), the UV detector being set at $280 \mathrm{~nm}$. Meanwhile, the separation of flavonoids was carried out on a Hypersil-ODS C18 column (particle size $5 \mu$ $\mathrm{m}, 4.6 \times 250 \mathrm{~mm}$ ) and the UV detector was set at $330 \mathrm{~nm}$. All analyses were performed at $35^{\circ} \mathrm{C}$; gradient elution was employed using acetonitrile-acetic acid mixtures as mobile phase, at a flow rate of $1 \mathrm{~mL} / \mathrm{min}$, and the injected volume was $10 \mu \mathrm{L}$ for both standard and tested samples. Authentic reference samples were prepared by diluting stock solutions with methanol to afford a $50 \mu \mathrm{g} / \mathrm{mL}$ final concentration. Identification of individual components was performed by comparing their retention times with those of the available standards similarly analyzed. Quantification was based on peak area computation using the external standard method. All analyses were carried out in triplicate. Samples were analyzed at 280 and $330 \mathrm{~nm}$, respectively.

\section{Antioxidant activity 2,2-Diphenyl-1-picrylhydrazyl (DPPH) radical scavenging assay}

The free radical-scavenging activities of the extracts of the four plants (prepared in the following solvents: $70 \%$ ethanol, methanol, acetone, and ethyl acetate) were measured through the hydrogen donating or radicalscavenging ability using the stable DPPH radical. The assay was performed in a 96-well microtiter plate using the modified previously described method [46]. Hundred $\mu \mathrm{l}$ of each of the samples and the standard solutions were mixed with $100 \mu \mathrm{l}$ of $0.1 \mathrm{mM}$ ethanolic DPPH solution in the wells. The reaction mixtures were shaken vigorously and incubated in dark for $30 \mathrm{~min}$ at $37{ }^{\circ} \mathrm{C}$. The absorbance was measured at $517 \mathrm{~nm}$ using UV-vis microplate reader. The percentage inhibition (\%) of the DPPH radical by the samples was calculated using the following formula:

$$
\% \text { inhibition }=\left[\mathrm{A}_{0}-\left(\mathrm{A}_{1}-\mathrm{A}_{2}\right)\right] / \mathrm{A}_{0} \times 100 \%
$$

Where $A_{0}$ is the absorbance of the control, $A_{1}$ is the absorbance in the presence of the sample and $A_{2}$ is the absorbance of the sample under identical conditions as 
$A_{1}$ with ethanol instead of DPPH solution. Ascorbic acid (AA) was used as a reference compound. $\mathrm{IC}_{50}$ values were calculated. Samples were analyzed in triplicate.

\section{Experimental design}

The residues of the ethanolic extracts for the four plants were suspended in $1 \% \mathrm{CMC}$. The animals were randomly assigned to 14 groups, of 6 animals each $(n=6)$. Table 1 describes the animal grouping with their corresponding treatment.

The first group served as normal control and during the experiment received vehicle only $(1 \% \mathrm{CMC})$. The second group was given $1 \%$ CMC solution for 14 days before $\mathrm{CCl}_{4}$ intoxication and served as a hepatotoxicity control group. For each plant, three groups were devoted; the first was treated with the plant extract twice daily for 14 days while the second and the third groups were given the plant extract in two different doses for 14 days as shown in Table 1. After the 14-days treatment period, hepatic injury was induced by intraperitoneal injection of $1.0 \mathrm{ml} / \mathrm{kg}$ of $\mathrm{CCl}_{4}$ and the mice were sacrificed six hours after the last treatment.

\section{Assay of liver enzyme}

Blood samples were collected from the hearts with the use of $5 \mathrm{ml}$ sterile syringe individually for each mouse and transferred into non-heparinized tubes immediately and used later for the analyses of liver enzymes: alanine aminotransferase (ALT), aspartate aminotransferase (AST) and alkaline phosphatase (ALP).

\section{Estimation of oxidative parameters}

Liver samples were surgically removed from the mice immediately and stored in $-80^{\circ}$ for further antioxidant enzyme assay including activity of catalase, superoxide dismutase, glutathione peroxidase and TBARS as per the method described by Abu-Gharbieh et al. [47]. The levels of total protein were determined in the serum of experimental animals by using the Lowry method and the bromocresol green method, respectively $[48,49]$.

\section{Histopathological study}

Liver samples were suspended in $10 \%$ formaldehyde for histological evaluation. These tissues were processed and embedded in paraffin wax. Sections of $5 \mu \mathrm{m}$ in thickness were cut and stained with hematoxylin and eosin (H\&E) and Periodic acid-Schiff (PAS) stains.

\section{Statically analysis}

The results were reported as Mean \pm Standard Deviation (S.D) from three repeated determination. The data obtained were statistically analyzed using One-way analysis of variance ANOVA, followed by Dunnett's multiple comparison test (DMCT). P-value of $<0.05$ was considered as statistically significant.

\section{Results}

Standardization of the plants extracts

Influence of extracting solvent on total phenolic and

flavonoid contents

Different solvents were used to select the most efficient, safe and applicable solvent for phenolic compounds extraction as shown in Table 2.

Spectrophotometric evaluation of the total phenolic content (expressed as mg gallic acid equivalent (mg GAE)/g dry plant material) and flavonoid content (as quercetin $\mathrm{g} /$ $100 \mathrm{~g}$ dry plant material) in the extracts of $F$. indica, C. procera and $Z$. hamiense revealed variable efficiency. Ethanol

Table 1 Animals groups and corresponding treatment with vehicle, tested samples and carbon tetrachloride

\begin{tabular}{llll}
\hline & Oral treatment & Frequency & i.p. CCl injection \\
\hline Control & Vehicle & daily & - \\
$\mathrm{CCl}_{4}$ control & Vehicle & daily & $1.0 \mathrm{ml} / \mathrm{kg}$ \\
F. indica extract & $10 \mathrm{mg} / \mathrm{kg}$ & Twice daily & - \\
& $5 \mathrm{mg} / \mathrm{kg}$ & daily & $1.0 \mathrm{ml} / \mathrm{kg}$ \\
& $10 \mathrm{mg} / \mathrm{kg}$ & daily & $1.0 \mathrm{ml} / \mathrm{kg}$ \\
Z. hamiense extract & $500 \mathrm{mg} / \mathrm{kg}$ & Twice daily & - \\
& $250 \mathrm{mg} / \mathrm{kg}$ & daily & $1.0 \mathrm{ml} / \mathrm{kg}$ \\
& $500 \mathrm{mg} / \mathrm{kg}$ & daily & $1.0 \mathrm{ml} / \mathrm{kg}$ \\
C. procera extract & $200 \mathrm{mg} / \mathrm{kg}$ & Twice daily & - \\
& $100 \mathrm{mg} / \mathrm{kg}$ & daily & $1.0 \mathrm{ml} / \mathrm{kg}$ \\
S. imbricata extract & $200 \mathrm{mg} / \mathrm{kg}$ & daily & $1.0 \mathrm{ml} / \mathrm{kg}$ \\
& $500 \mathrm{mg} / \mathrm{kg}$ & Twice daily & - \\
& $250 \mathrm{mg} / \mathrm{kg}$ & Daily & $1.0 \mathrm{ml} / \mathrm{kg}$ \\
\hline
\end{tabular}


Table 2 Total Flavonoid and phenolic acid contents of the different extracts of Fagonia indica, Calotropis procera, Zygophyllum hamiense and S.imbricata

\begin{tabular}{|c|c|c|c|c|c|c|c|c|}
\hline \multirow[t]{2}{*}{ Plant name } & \multicolumn{4}{|c|}{ Total flavonoid content g quercetin/100 g } & \multicolumn{3}{|c|}{ Total phenolic content mg GAE/g } & \multirow[b]{2}{*}{$\begin{array}{l}\text { Ethyl acetate } \\
\text { extract }\end{array}$} \\
\hline & $\begin{array}{l}\text { Methanol } \\
\text { extract }\end{array}$ & $\begin{array}{l}\text { Ethanol } \\
\text { extract }\end{array}$ & $\begin{array}{l}\text { Acetone } \\
\text { extract }\end{array}$ & $\begin{array}{l}\text { Ethyl acetate } \\
\text { extract }\end{array}$ & $\begin{array}{l}\text { Methanol } \\
\text { extract }\end{array}$ & $\begin{array}{l}\text { Ethanol } \\
\text { extract }\end{array}$ & $\begin{array}{l}\text { Acetone } \\
\text { extract }\end{array}$ & \\
\hline F. indica & 0.22 & 3.00 & 0.32 & 0.10 & 3.91 & 4.00 & 2.1 & 0.75 \\
\hline C. procera & 0.12 & 0.3 & 0.90 & 0.10 & 3.13 & 4.00 & 4.00 & 0.92 \\
\hline Z. hamiense & 0.38 & 0.14 & 1.48 & 0.11 & 2.60 & 3.61 & 1.20 & 4.00 \\
\hline S. imbricata ${ }^{a}$ & 0.571 & 0.217 & 0.374 & 0.11 & 2.60 & 0.64 & 4.00 & 0.93 \\
\hline
\end{tabular}

${ }^{\mathrm{a}}$ Results previously reported [39]

was found to be the best solvent for extracting the $F$. indica sample with highest concentration of phenolics $(4 \mathrm{mg}$ GAE/g dry plant wt.) and flavonoids (3 g quercetin (Q) \% w/dry plant wt.). Concerning C. procera, the highest flavonoid content was detected when using acetone $(0.9 \mathrm{~g} \mathrm{Q}$ $\%$ w/dry wt.), while both ethanol and acetone extracts were found the richest in total phenolics (4 mg GAE/g dry wt.). On the other hand, the maximum flavonoid amount $(1.48 \%)$ was extracted with acetone in $Z$. hamiense, meanwhile ethyl acetate and ethanol appeared of close efficiencies for solubilisation of total phenolics (4 and $3.61 \mathrm{mg}$ GAE/g dry plant wt., respectively). Finally, among the tested plants and including $S$. imbricata, the most enriched sample in both total phenolics and flavonoids was F. indica (4 mg GAE/g of plant dry wt. and $3 \mathrm{~g} \% \mathrm{w} /$ dry wt., expressed as quercetin respectively).

\section{RP-HPLC profiling of phenolics}

RP-HPLC analysis and total phenolic and flavonoid contents of S. imbricata were previously determined [39]. RP-HPLC analyses of the methanolic extracts of the remaining three plants, $F$. indica, $C$. procera, and $Z$. hamiense, allowed the identification and quantitation of several phenolics. Total of 14 components were identified at $280 \mathrm{~nm}$ in both C. procera and F. indica (corresponding to 10.297 and $7.955 \%$ of the total composition, respectively) and 13 components in $Z$. hamiense (corresponding to $19.52 \%$ ) as shown in Table 3. Among these, the identified phenolic acids were 10 in $F$. indica (representing $4.84 \%), 9$ in C. procera (6.274 \%) and 8 in Z. hamiense $(11.35 \%)$. Ellagic and non-phenolic benzoic acids (1.2 and $1.02 \%$ ) were the prevalent in F. indica while in C. procera, benzoic and salicylic acids (1.59 and $1.53 \%)$ were the

Table 3 Phenolics identified by RP-HPLC analysis (at $\lambda=280 \mathrm{~nm}$ ) of the methanolic extracts of Fagonia indica, Calotropis procera, Zygophyllum hamiense and S.imbricata

\begin{tabular}{|c|c|c|c|c|c|}
\hline \multirow[t]{2}{*}{ Retention time } & \multirow[t]{2}{*}{ Identified constituent } & \multicolumn{4}{|c|}{ Relative area \% } \\
\hline & & F. indica & C. procera & Z. hamiense & S. imbricata \\
\hline 6.81 & Pyrogallol & 0.145 & 0.173 & 1.94 & - \\
\hline 6.92 & Gallic acid & 0.05 & 0.27 & 2.02 & 0.145 \\
\hline 8.235 & Protocatechuic acid & 0.12 & 0.504 & 0.97 & 0.068 \\
\hline 8.444 & Catechin & - & 0.38 & 1.81 & 0.461 \\
\hline 8.593 & Chlorogenic acid & 0.46 & 0.12 & 2.31 & 0.377 \\
\hline 8.950 & Catechol & 0.16 & 0.44 & 2.57 & 0.329 \\
\hline 10.040 & Caffeic acid & 0.25 & - & 1.54 & 1.759 \\
\hline 11.073 & Vanillic acid & 0.37 & 0.82 & 1.37 & 0.286 \\
\hline 11.620 & Ferulic acid & 0.34 & 0.36 & 0.84 & 1.323 \\
\hline 12.466 & Salicylic acid & 0.73 & 1.53 & 1.1 & 1.154 \\
\hline 12.943 & Ellagic acid & 1.20 & 1.20 & - & - \\
\hline 13.127 & Benzoic acid & 1.02 & 1.59 & 1.51 & 2.306 \\
\hline 13.789 & Coumaric acid & 0.51 & 0.52 & 1.2 & 4.251 \\
\hline 14.980 & Cinnamic acid & 0.81 & 0.95 & - & 0.371 \\
\hline 18.657 & Chrysin & 1.79 & 1.44 & 0.34 & 1.074 \\
\hline \multicolumn{2}{|c|}{ Total identified constituents } & 7.955 & 10.297 & 19.52 & 13.904 \\
\hline
\end{tabular}

${ }^{\mathrm{a}}$ Results previously reported [39] 
Table 4 Phenolics identified by RP-HPLC analysis (at $\lambda=330 \mathrm{~nm}$ ) of the methanolic extracts of Fagonia indica, Calotropis procera, Zygophyllum hamiense and S.imbricata

\begin{tabular}{|c|c|c|c|c|c|}
\hline \multirow[t]{2}{*}{ Retention time } & \multirow[t]{2}{*}{ Identified constituent } & \multicolumn{4}{|c|}{ Relative area \% } \\
\hline & & F. indica & C. procera & Z. hamiense & S. imricata ${ }^{a}$ \\
\hline 3.83 & Quercetin & 0.034 & 0.08 & 0.04 & 0.031 \\
\hline 11.78 & Rosmarinic acid & 2.83 & 2.68 & 2.33 & 2.734 \\
\hline 12.06 & Hesperidin & 1.21 & 2.22 & - & 1.854 \\
\hline 12.44 & Rutin & - & 1.72 & 10.71 & 2.101 \\
\hline 13.267 & Quercitrin & 5.29 & 4.16 & 0.77 & 12.692 \\
\hline 14.576 & Naringenin & 1.36 & 1.15 & 0.94 & 1.300 \\
\hline 14.952 & Hesperitin & 1.41 & - & - & 0.730 \\
\hline 15.147 & Kampferol & 1.61 & 1.5 & - & - \\
\hline 16.167 & Apigenin & 1.00 & 0.21 & - & 0.474 \\
\hline Total identified constituents & & 14.744 & 13.72 & 14.79 & 21.916 \\
\hline
\end{tabular}

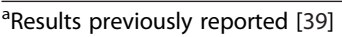

major. On the other hand, chlorogenic and gallic acids were predominant in $Z$. hamiense (2.31 and $2.02 \%$ ). In contrast, 9 phenolic acids $(9.734 \%)$ with prevalence of coumaric acid (4.251\%) were detected in S. imbricata [39]. On the other hand, by setting the detector at $\lambda=$ $330 \mathrm{~nm}, 8$ components were identified in both $F$. indica and $C$. procera among which 7 were of flavonoidal nature with major quercitrin (5.29 and $4.16 \%$ respectively) while 5 components only were determined in $Z$. hamiense among which 4 were of flavonoidal nature with major rutin $(10.71 \%)$ while quercitrin was the minor $(0.77 \%)$ as shown in Table 4. Alternatively, 7 flavonoidal components with major quercitrin (12.692\%) were previously detected in S. imbricata. Besides, rosmarinic acid was detected in all samples under investigation with relatively appreciable amounts (Table 4).

\section{DPPH free radical scavenging activity}

DPPH is a stable free radical and its noticeable purple color shows absorption at $517 \mathrm{~nm}$. Antioxidants scavenge the free radical by donating a hydrogen atom and the color of the DPPH assay solution becomes yellowish, resulting in a decrease of the absorbance. DPPH free radical scavenging activity is considered as in vitro screening for possible in vivo antioxidant potentialities.

The four plants were tested and the results are presented in Fig. 1. All extracts were found to be potent $\mathrm{DPPH}$ free radical scavengers and the highest activity

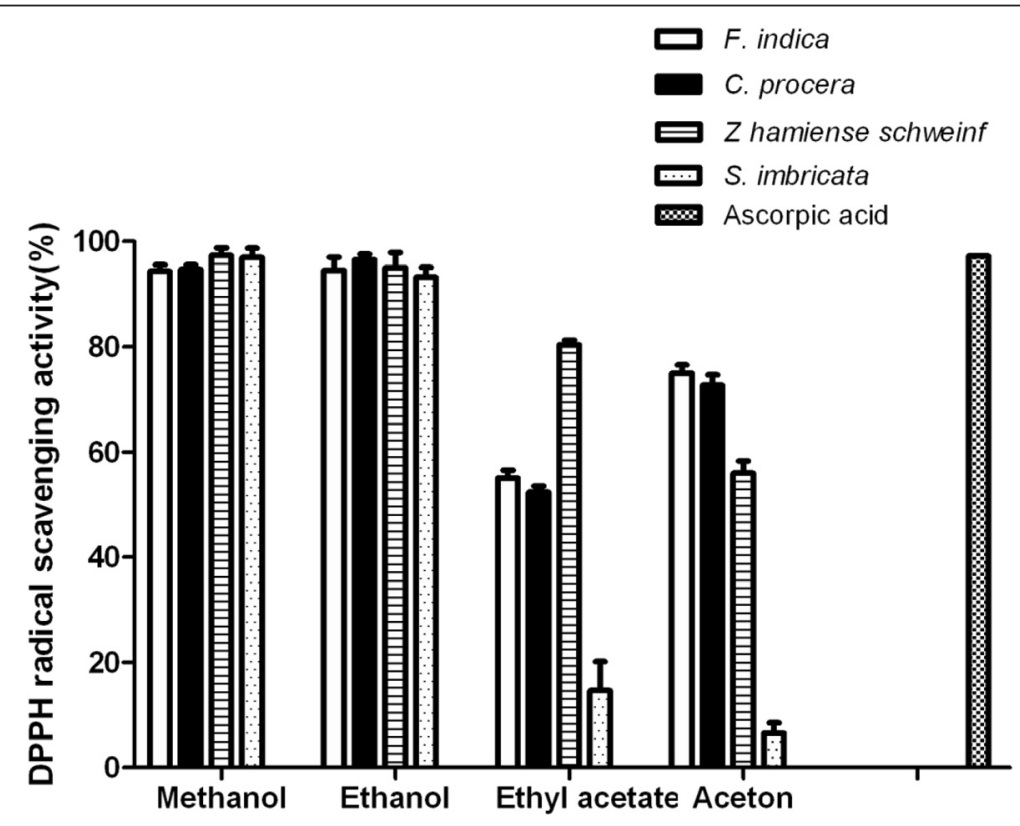

Fig. 1 DPPH radical scavenging activity of several plants extracts 
among all investigated plants samples was observed for the ethanolic and methanolic extracts as shown in Fig. 1.

\section{Acute toxicity study}

The acute toxicity study was essential to evaluate the plants extracts safety and to determine the tested doses.

The $\mathrm{LD}_{50}$ of both F. indica and S. imbricata extracts had been previously reported and they were found to be safe up to 4 and $5 \mathrm{~g} / \mathrm{kg}$ respectively $[11,39]$. $Z$. hamiense was found to be safe up to dose $5 \mathrm{~g} / \mathrm{kg}$ while C. procera leaves extract was safe up to $3 \mathrm{~g} / \mathrm{kg}$. No signs of morbidity or behavioral changes in any of the treated groups of animals during the period of observation. The safety margin of the ethanolic extracts of the plants under investigation is highly encouraging the biological evaluation.

\section{Effects on liver enzymes and histological findings}

The plants extracts were given twice daily over two weeks in order to evaluate any possible hepatotoxicity caused by the plants extracts themselves. Moreover, this was useful to evaluate the effect of the extracts on the antioxidant enzyme system apart from the $\mathrm{CCl}_{4}$ challenge.

Treating the animals twice daily with the plants extracts alone over two weeks, did not cause any significant elevation on both the ALT and AST as shown in Table 5. On the other hand, significant reduction in ALP levels was observed by administration of the ethanolic extracts of the four plants. This indicates that no possible cholestasis occurred at the dose levels tested since a rise in plasma ALP level is usually a characteristic feature in cholestatic liver disease [50]. Moreover, histological assessment revealed that the hepatocytes maintained its architecture with normal glycogen storage. This gave evidence that the four plants did not produce any harmful on the hepatocytes as shown in Fig. 2a. Beside this, treating the animals with the plants extracts did not show any significant enhancement of the antioxidant enzyme system.

Results in Table 6, showed that $\mathrm{CCl}_{4}$ caused sharp and significant elevation in liver enzymes, ALT and AST by
$598 \%$ and $204 \%$ respectively compared to control group $(p<0.01)$, while ALP was not significantly affected. Histological data revealed a dense periportal and lobular lymphocytic infiltrate with diffused pyknotic nuclei within necrotic hepatocytes in periportal areas. Fig. $2 \mathrm{~b}$.

Pre-treating the mice with $F$. indica, C. procera and $S$. imricata extracts at the highest and lowest doses for 14 days prior $\mathrm{CCl}_{4}$ administration showed significant reduction in serum levels of ALT, AST but not ALP enzymes in a dose response manner ( $p$-value less than 0.05 and 0.01 , respectively). Those findings are supported by the histological features; hepatocytes renewal and regeneration with mild glycogen depletion were observed with F. indica, C. procera and S. imbricata only as shown in Figs. 2c, d and e. On the other hand, pretreating the animals with $Z$. hamiense extract at both doses showed significant reduction in AST level $(p<0.01)$ though ALT and ALP levels were not changed $(p>0.05)$. Furthermore, histological study showed centralized gross glycogen depletion (Fig. 2f).

\section{Effects on antioxidant enzymes and TBARS contents}

Hepatotoxicity induced by $\mathrm{CCL}_{4}$ is characterized by suppression of the antioxidant defense system [51-53] and increased lipid peroxidation [51].

Administration of $\mathrm{CCl}_{4}$ markedly depleted the antioxidant enzymes (CAT, GSH-Px and SOD) in the mice livers (Table 6). Nevertheless, $\mathrm{CCl}_{4}$ increased significantly $(p<$ $0.01)$ the hepatic lipid peroxidation that is expressed by high TBARS content. Whereas the administration of plants extracts twice daily for two weeks did not result in significant enhancement of the antioxidant enzymes nor reduction in the TBARS content as shown in Table 5.

Pretreating the animals with the plants extracts at different doses opposed significantly the reduction in the antioxidant enzymes and reduced markedly the TBARS content induced by $\mathrm{CCl}_{4}$ except for $\mathrm{Z}$. hamiense extract that has no potential effects on the antioxidant enzymes as well as the TBARS content.

Table 5 Evaluation of the hepatotoxic effect of the plant extracts on the biochemical parameters with twice daily oral administration in mice

\begin{tabular}{lccccc}
\hline & Control & F. indica & Z hamiense & C. procera & S. imbricata \\
\hline ALT & $290.1 \pm 54.0$ & $350.2 \pm 113.6$ & $155.3 \pm 65.5$ & $211.0 \pm 35.8$ & $253.3 \pm 24.0$ \\
AST & $850.0 \pm 63.2$ & $800.0 \pm 235.8$ & $520.3 \pm 220.0$ & $404.2 \pm 37.2^{\mathrm{b}}$ & $653.3 \pm 78.8$ \\
ALP & $180.0 \pm 20.3$ & $113.3 \pm 16.7^{\mathrm{a}}$ & $105.6 \pm 15.4^{\mathrm{a}}$ & $98.2 \pm 9.3^{\mathrm{b}}$ & $60.0 \pm 23.1^{\mathrm{b}}$ \\
CAT kU/g protein & $462.0 \pm 21.1$ & $461.6 \pm 14.9$ & $428.750 \pm 10.3$ & $413.950 \pm 11.4$ & $486.3 \pm 18.0$ \\
GSH-Px U/g protein & $1.3 \pm 0.1$ & $1.3 \pm 0.05$ & $1.3 \pm 0.07$ & $1.6 \pm 0.06$ & $1.31 \pm 0.14$ \\
SOD $\mu$ g/g protein & $34.6 \pm 2.9$ & $35.5 \pm 2.7$ & $32.8 \pm 1.1$ & $35.5 \pm 1.4$ & $32.1 \pm 1.4$ \\
TBARS (nmol/g prot.) & $0.49 \pm 0.02$ & $0.39 \pm .03$ & $0.046 \pm 0.03$ & $0.038 \pm 0.02$ & $0.035 \pm 0.4$ \\
\hline
\end{tabular}

${ }^{\mathrm{a}}$ Significant difference $(p<0.05)$ compared to control group; ${ }^{\mathrm{b}}$ Significant difference $(p<0.01)$ compared to control group 

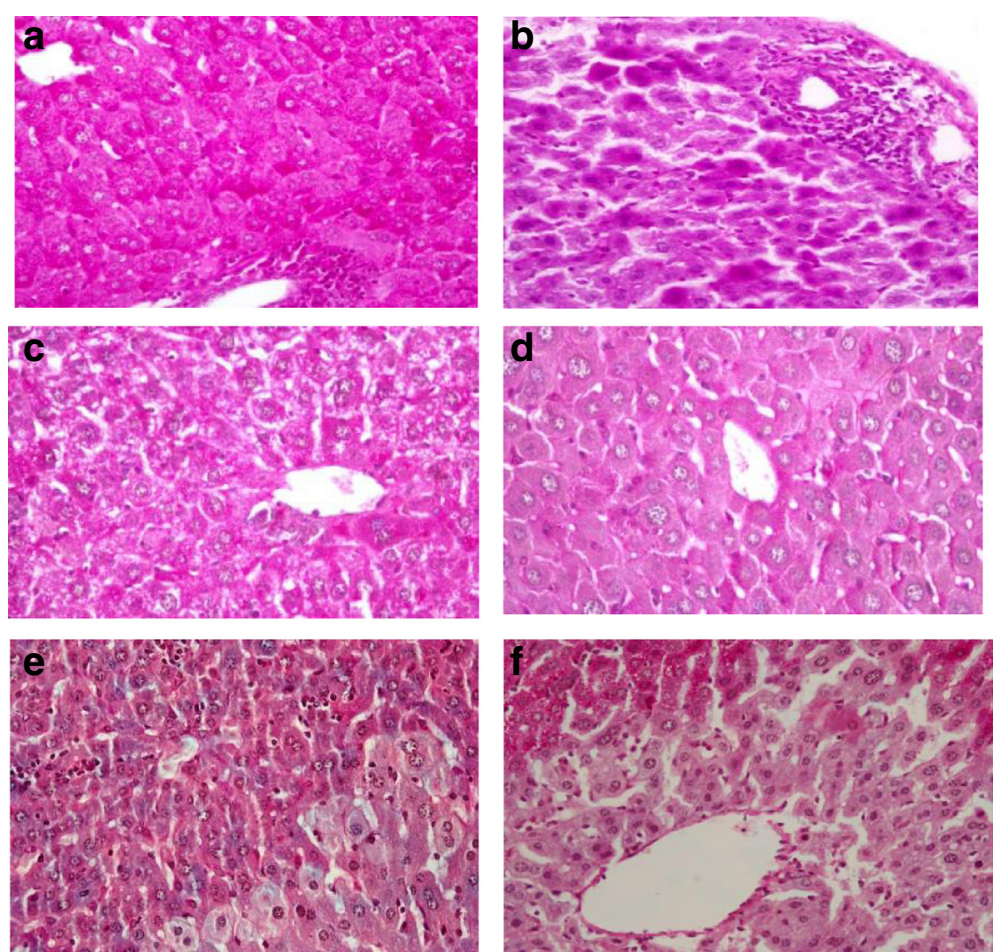

Fig. 2 Histopathological findings of mice liver sections (PAS x400); (a) treated with $10 \mathrm{mg} / \mathrm{kg} F$. indica twice daily showing excess glycogen synthesis; (b) negative control group treated with $\mathrm{CCl}_{4}$ alone showing dense periportal and lobular lymphocytic infiltrate with pyknotic nuclei within necrotic hepatocytes in periportal areas and some other cells show degenerative changes; (c) treated with $10 \mathrm{mg} / \mathrm{kg}$ F. indica and $\mathrm{CCl}_{4}$ showing normal regenerating hepatocytes sometimes binucleated; (d) treated with 200mg/kg C. procera and CCl 4 showing normal glycogen storage, stimulates regeneration and renewal of hepatocytes; (e) treated with $500 \mathrm{mg} / \mathrm{kg} \mathrm{S}$. imbricata and CCl showing slight glycogen depletion and $(\mathbf{f})$ treated with $Z$. hamiense Schweinf and $\mathrm{CCl}_{4}$ showing glycogen depletion in centrizonal area and more glycogen and ballooning degeneration on peripheral zone

\section{Discussion}

Liver diseases are one of the major causes of morbidity and mortality and affects people of all ages throughout the world especially in the Arab countries. The drugs that are currently available to treat this condition pose serious drawbacks [5], which justifies the search for new hepatoprotective agents. In this context, the use of plants extracts and isolates therefrom with hepatoprotective properties can provide beneficial means for prevention and treatment of liver conditions.

Alanine aminotransferase (ALT), aspartate aminotransferase (ASL) are present mostly in the hepatic and biliary cells [54]. These enzymes are usually released from the hepatocytes and leak into circulation causing increase in their serum levels under hepatocellular injury or inflammation of the biliary tract cells resulting predominantly in an elevation of the alkaline phosphatase levels. On the other hand, elevation in ALP is usually indicates a cholestatic liver diseases.

Chronic administration of the four plants extracts for two weeks resulted in significant reduction in alkaline phosphatase levels. This shows that no possible cholestasis occurred at the dose levels tested since a rise in plasma ALP level is usually a characteristic finding in cholestatic liver diseases [50]. This was further confirmed by the fact that there were no significant changes in ALT and AST. Accordingly the plants extracts did not exhibit any signs of hepatotoxicity on chronic administration.

In this study, we were focusing on the liver injury that always accompanied by elevated levels of serum hepatic enzymes that are indicative of cellular leakage [55]. The hepatotoxic effects induced by $\mathrm{CCl}_{4}$ are related to its active metabolite trichloromethyl radical, ${ }^{\circ} \mathrm{CCl}_{3}$, this is manifested by marked elevation in the serum liver enzymes namely AST, ALT, ALP [52]. Antioxidant enzymes, particularly, CAT, GSH-Px and SOD play a vital role in protecting cells against oxidative damage. Administration of $\mathrm{CCl}_{4}$ to the animals leads to induction of hepatic oxidative stress that is characterized by significant decrease in CAT, GSH-Px and SOD activities and increased TBARS content in liver tissue [52].

It was found that phenolic, especially polyphenolic, compounds such as flavonoids are very efficient scavengers of free radicals [56] because of their molecular structures, which include an aromatic ring with hydroxyl groups containing mobile hydrogen. Actually, it is 
Table 6 Evaluation of the protective effect of the plants extracts on the biochemical parameters of liver in $\mathrm{CCl}_{4}$-induced hepatic damage in mice

\begin{tabular}{|c|c|c|c|c|c|c|c|c|c|c|}
\hline & \multirow[t]{2}{*}{ Control } & \multirow[t]{2}{*}{$\mathrm{CCl}_{4}$ control } & \multicolumn{2}{|l|}{ F. indica } & \multicolumn{2}{|l|}{$Z$ hamiense } & \multicolumn{2}{|l|}{ C. procera } & \multicolumn{2}{|l|}{ S. imbricata } \\
\hline & & & $5 \mathrm{mg} / \mathrm{kg}$ & 10 mg/kg & $250 \mathrm{mg} / \mathrm{kg}$ & $500 \mathrm{mg} / \mathrm{kg}$ & 100 mg/kg & 200 mg/kg & $250 \mathrm{mg} / \mathrm{kg}$ & $500 \mathrm{mg} / \mathrm{kg}$ \\
\hline $\mathrm{ALT}(\mathrm{U} / \mathrm{L})$ & $290.1 \pm 54.0$ & $1736.7 \pm 161.2^{a}$ & $2166.7 \pm 157.8^{b}$ & $1064.0 \pm 264.9^{c}$ & $1416.7 \pm 105.8$ & $950.3 \pm 84.4$ & $1054.3 \pm 117.5^{c}$ & $801.7 \pm 76.0^{c}$ & $1135.0 \pm 127.9^{c}$ & $476.7 \pm 151.0^{c}$ \\
\hline AST(U/L) & $850.0 \pm 63.2$ & $1736.7 \pm 215.1^{a}$ & $1310.0 \pm 181.5^{b}$ & $926.2 \pm 258.6^{c}$ & $756.7 \pm 128.6^{c}$ & $783.3 \pm 80.1^{c}$ & $787.8 \pm 69.6^{c}$ & $922.7 \pm 65.4^{c}$ & $647.5 \pm 62.8^{c}$ & $530.0 \pm 120.8^{c}$ \\
\hline ALP(U/L) & $180.0 \pm 20.3$ & $150.2 \pm 55.7$ & $125.0 \pm 22.5$ & $124.3 \pm 17.4$ & $106.7 \pm 24.0$ & $113.3 \pm 29.1$ & $51.8 \pm 4.7$ & $59.5 \pm 6.1^{c}$ & $110.0 \pm 14.7$ & $63.3 \pm 8.8$ \\
\hline CAT kU/g protein & $462.0 \pm 21.1$ & $241.3 \pm 11.4^{\mathrm{a}}$ & $307.2 \pm 9.2^{c}$ & $392.200 \pm 9.4^{c}$ & $225.1 \pm 10.5$ & $259.1 \pm 5.1$ & $324.7 \pm 25.8^{b}$ & $335.0 \pm 25.0^{c}$ & $356.2 \pm 24.1^{c}$ & $374.9 \pm 10.7^{c}$ \\
\hline GSH-Px U/g protein & $1.3 \pm 0.1$ & $0.85 \pm 0.06^{\mathrm{a}}$ & $1.1 \pm 0.2$ & $1.2 \pm 0.2$ & $0.72 \pm 0.1$ & $0.94 \pm 0.2$ & $1.4 \pm 0.06$ & $1.4 \pm 0.06$ & $0.91 \pm 0.06$ & $1.39 \pm 0.19^{b}$ \\
\hline SOD $\mu g / g$ protein & $34.6 \pm 2.9$ & $22.0 \pm 2.4^{a}$ & $26.7 \pm 1.8$ & $32.9 \pm 1.6^{c}$ & $21.1 \pm 1.7$ & $23.6 \pm 1.5$ & $22.7 \pm 1.2$ & $31.5 \pm 1.1^{\mathrm{b}}$ & $24.8 \pm 0.5$ & $26.4 \pm 1.3$ \\
\hline TBARS (nmol/g prot.) & $0.049 \pm 0.02$ & $0.54 \pm 0.20^{a}$ & $0.12 \pm 0.09^{c}$ & $0.085 \pm 0.05^{c}$ & $0.42 \pm 0.2$ & $0.36 \pm 0.4$ & $0.14 \pm 0.07^{c}$ & $0.06 \pm 0.01^{c}$ & $0.11 \pm 0.05^{c}$ & $0.071 \pm 0.02^{c}$ \\
\hline
\end{tabular}

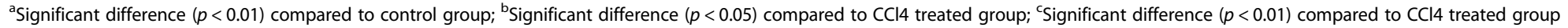


known that the 3',4'-ortho-dihydroxy group in the B-ring and the $5-\mathrm{OH}$ group in the A-ring with a 4-carbonyl group are required for the high antioxidant activity of flavonoids. In addition, the presence of the $o$-catechol group $\left(3^{\prime}, 4^{\prime}-\mathrm{OH}\right)$ in the flavonoid-B ring is a determinant for high antioxidant capacities in flavonoids (Fig. 3), [57]. The flavonoid content of Fagonia indica exceeded those of the other plants by 10 to 30 folds. The phenolic content of Salsola imbricata extract was previously reported to be $0.571 \%$ [39]; while Calotropis procera extract showed high phenolic acids content. The frequently used DPPH assay was applied as a first in vitro approach to assess the free radical-scavenging activity of the plants extracts prepared in the different solvents. This evaluation revealed that the methanolic and ethanolic extracts of the four plants exhibited the highest DPPH radical scavenger potential with activity comparable to those of ascorbic acid, a well-known antioxidant. However, for safety and economic considerations, the ethanol (70 \%) was selected for further biological study.

Dose selection for the subsequent biological study for the three plants (Zygophyllum hamiense, Calotropis procera and Salsola imbricata) was based on their $\mathrm{LD}_{50}$ values (less than $1 / 10$ of $\mathrm{LD}_{50}$ ). Moreover, the major influencing factors to select smaller doses for Fagonia indica extract ( 5 and $10 \mathrm{mg} / \mathrm{kg}$ ) was the extremely high contents of flavonoid and phenolic acid compared to the other plants extracts. Additionally, similar doses of Fagonia indica were tested previously for its analgesic effect [11].

The three plants, Fagonia indica, Calotropis procera and Salsola imbricata possessed high antioxidant and hepatoprotective activities. These effects may be attributed to the presence of high content of different groups of phenolic compounds including flavonoids aglycone and/or glycosides and phenolic acids especially quercetrin glycoside and rosmarinic acid (Fig. 3) that have been earlier reported to exhibit strong antioxidant and hepatoprotective effects $[58,59]$. Moreover, hesperidin and its aglycone hesperitin, apigenin and cinnamic acid that exhibited strong antioxidant and hepatoprotective activities [60-64] were detected in all plants extracts except Zygophyllum hamiense of which rutin was the predominant flavonoid $(10.71 \%)$. The presence of high rutin concentration in Zygophyllum hamiense extract explains its in vitro free radical scavenging activity and possibly it's in vivo effect on AST level. Anyway, the plant could not be considered as hepatoprotective since ALT level, that is thought to be more specific for hepatic injury [54], was not significantly improved. Accordingly, the lack of other flavonoids especially quercetrin that presents in the other three plants explains the weak in vivo antioxidant and hepatoprotective activities of Zygophyllum hamiense against $\mathrm{CCl}_{4}$ intoxication.

Interestingly, it was found that although S. imbricata contains the lowest amount of phenolic contents, its efficacy in reducing ALT level in $\mathrm{CCL}_{4}$ treated mice still high. This can be explained by the presence of triterpenoid saponin. Two triterpenoidal saponin glycosides were isolated and identified from the S. imbricata, namely, salisomide and salisoflavan [38], and it is reported in literature that saponins interact with and increase permeability of the mucosal cells in the gut and enhance the absorption of various nutrient $[65,66]$. Therefore, saponin enhanced the absorption of phenolic compounds. Additionally, saponins themselves possess antioxidant activity that contributes to efficacy of the phenolic compounds to protect against liver injury induced by $\mathrm{CCL}_{4}[67,68]$.

Based on that, it was found that F. indica, C. procera and $S$. imbricata possess hepatoprotective effects by preventing the induction of oxidative stress and enhancing the hepatic antioxidant defences involving CAT, GSH-PX and SOD enzymes and were highly efficient in reducing the TBARS content in liver tissue. Accordingly, the three plants could be added to the growing list of medicinal plants. Further clinical studies are needed to evaluate their clinical significance.

\section{Conclusion}

In conclusion, this study evidences the efficiency of the ethanolic extracts of $F$. indica, C. procera and S. imbricata

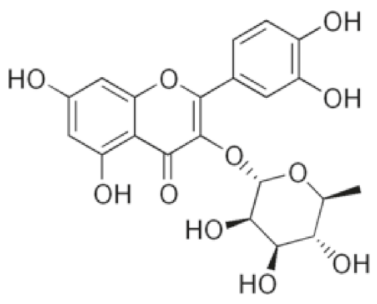

Quercitrin

Fig. 3 Chemical structures of quercitrin and rosmarinic acid<smiles>O=C(/C=C/c1ccc(O)c(O)c1)OC(Cc1ccc(O)c(O)c1)C(=O)O</smiles>

Rosmarinic acid 
in preventing the $\mathrm{CCl}_{4}$-induced hepatotoxicity in mice through scavenging of free radicals and by boosting the antioxidant capacity of the liver. The bioactive antioxidant principles detected in the extracts are probably responsible for this hepatoprotective effect. Therefore the parent plants could be considered as a potential source of safe protective from liver diseases or for reduction of undesirable hepatotoxic side effects of some drugs.

\section{Competing interests}

The authors declare that there is no conflict of interests.

\section{Authors' contributions}

Naglaa Gamil and Eman Abu-Gharbieh were responsible for designing the experimental work and manuscript writing and publication. Specifically, Naglaa Gamil was responsible for the idea, plants extraction, interpreted the HPLC results and carried the quantitative analysis of total phenolic and flavonoid. Eman Abu-Gharbieh designed and carried out the the in-vitro, in-vivo experiments, statistical data and results analysis. Fatehia A.Bayoumi carried out the histological study. All authors approved the final article.

\section{Acknowledgments}

The authors want to thank Professor Saeed Ahmed Khan - Dean of Dubai Pharmacy College for his support in all the research steps.

\section{Author details}

'Department of Pharmacognosy, Faculty of Pharmacy, Cairo University, Cairo, Egypt. ${ }^{2}$ Department of Pharmacology and Toxicology, Dubai Pharmacy College, Al-Nahda 3, Dubai, UAE. ${ }^{3}$ Department of Pathology, Dubai Medical College, Al-Nahda 3, Dubai, UAE.

Received: 16 July 2015 Accepted: 14 October 2015

Published online: 09 November 2015

\section{References}

1. Oberley LW. Free radicals and diabetes. Free Radic Biol Med. 1988:5:113-24.

2. Slater TF. Free-radical mechanisms in tissue injury. Biochem J. 1984;222:1-15.

3. Williams R. Global challenges in liver disease. Hepatology. 2006;44:521-6.

4. Bruck R, Hershkoviz R, Lider O, Aeed H, Zaidel L, Matas Z, et al. Inhibition of experimentally-induced liver cirrhosis in rats by a nonpeptidic mimetic of the extracellular matrix-associated Arg-Gly-Asp epitope. J Hepatol. 1996;24:731-8

5. Fujisawa K, Tandon BN. Therapeutic Approach to the Chronic Active Liver Disease: Summary of a Satellite Symposium. In: Nishioka K, Suzuki H, Mishiro S, Oda T (eds). Viral Hepatitis and Liver Disease. Tokyo: Springer Japan; 1994;662-5

6. Hung TM, Na M, Thuong PT, Su ND, Sok D, Song KS, et al. Antioxidant activity of caffeoyl quinic acid derivatives from the roots of Dipsacus asper Wall. J Ethnopharmacol. 2006;108:188-92.

7. Lee S, Son K, Chang H, Do J, Jung K, Kang S, et al. Antiinflammatory activity of naturally occurring flavone and flavonol glycosides. Arch Pharm Res. 1993;16:25-8.

8. Vessal M, Hemmati M, Vasei M. Antidiabetic effects of quercetin in streptozocin-induced diabetic rats. Comp Biochem Physiol C Toxicol Pharmacol. 2003;135C:357-64.

9. Vivian Cody, Elliott Middleton, Jeffrey B.Harborne. Plant flavonoids in biology and medicine. Biochemical, pharmacological, and structure-activity relationships. Proceedings of a symposium. Buffalo, New York, July 22-26, 1985. 1985. Ref Type: Conference Proceeding

10. Shaikh R, Pund M, Dawane A, lliyas S. Evaluation of Anticancer, Antioxidant, and Possible Anti-inflammatory Properties of Selected Medicinal Plants Used in Indian Traditional Medication. J Tradit Complement Med. 2014;4:253-7.

11. Naglaa GS, Amina M. Constituents and analgesic activity of the alcoholic extract of Fagonia indica Burm F. New Egypt J Med. 2009;40:357-71.

12. Bagban IM, Roy SP, Chaudhary A, Das SK, Gohil KJ, Bhandari KK. Hepatoprotective activity of the methanolic extract of Fagonia indica Burm in carbon tetra chloride induced hepatotoxicity in albino rats. Asian Pac J Trop Biomed. 2012;2:S1457-60.
13. Rameshkumar S, Eswaran K. Ecology, Utilization and Coastal Management of Salt Tolerant Plants (Halophytes And Mangroves) of Mypad Coastal Regions, Andhra Pradesh, India. Int J Environ Biol. 2013;3:1-8.

14. Agharkar SP. Medicinal plant of Bombay presidency. India: Scientific publication; 1991.

15. Murti Y, Yogi B, Pathak D. Pharmacognostic standardization of leaves of Calotropis procera (Ait.) R. Br. (Asclepiadaceae). Int J Ayurveda Res. 2010;1:14-7.

16. Ramachandra Setty S, Quereshi AA, Viswanath Swamy AHM, Patil T, Prakash T Prabhu K, et al. Hepatoprotective activity of Calotropis procera flowers against paracetamol-induced hepatic injury in rats. Fitoterapia. 2007;78:451-4.

17. Kumar S, Gupta A, Pandey AK. Calotropis procera Root Extract Has the Capability to Combat Free Radical Mediated Damage. ISRN Pharmacol. 2013;2013:691372

18. Chaudhary P, de Araújo Viana C, Ramos MV, Kumar VL. Antiedematogenic and antioxidant properties of high molecular weight protein sub-fraction of Calotropis procera latex in rat. J Basic Clin Pharm. 2015;6:69-73.

19. Kumar VL, Padhy BM. Protective effect of aqueous suspension of dried latex of Calotropis procera against oxidative stress and renal damage in diabetic rats. Biocell. 2011;35:63-9.

20. Mohamed MA, Hamed MM, Ahmed WS, Abdou AM. Antioxidant and cytotoxic flavonols from Calotropis procera. Z Naturforsch C. 2011;66:547-54.

21. Moustafa AM, Ahmed SH, Nabil ZI, Hussein AA, Omran MA. Extraction and phytochemical investigation of Calotropis procera: effect of plant extracts on the activity of diverse muscles. Pharm Biol. 2010;48:1080-190.

22. Kakkar A, Verma DR, Suryavanshi S, Dubey P. Characterization of chemical constituents of Calotropis procera. Chem Nat Compd. 2012;48:155-7.

23. Shehab N. Volatiles, Lipoids and Flavonoids of the Flowers of Calotropis procera R.Br.: Composition and Bioactivity. Bull Fac Pharm Cairo Univ. 2008;46:139-49.

24. Elgamal MH, Shaker KH, Pollmann K, Seifert K. Triterpenoid saponins from Zygophyllum species. Phytochemistry. 1995;40:1233-6.

25. Jaouhari JT, Lazrek HB, Jana M. The hypoglycemic activity of Zygophyllum gaetulum extracts in alloxan-induced hyperglycemic rats. J Ethnopharmacol. 2000;69:17-20.

26. Ghoul JE, Boughattas NA, Ben-Attia M. Antihyperglycemic and antihyperlipidemic activities of ethanolic extract of Zygophyllum album in streptozotocin-induced diabetic mice. Toxicol Ind Health. 2013;29:43-51.

27. Belguidoum $M$, Dendougui $H$, Kendour $Z$. In vitro antioxidant properties and phenolic contents of Zygophyllum album L. from Algeria. J Chem Pharm Res. 2015;7:510-4.

28. Bayarmaa J, Antbagu M. Effect ZygophyllIm potaninii Maxim on histopathologicaland enzymatic chances in experimental liver Injury of rats. Mongolian J Health Sci. 2006;3(1):53-58.

29. Yildiztugay E, Ozfidan-Konakci C. Profiling of rutin-mediated alleviation of cadmium-induced oxidative stress in Zygophyllum fabago. Environ Toxicol. 2015;30:816-35.

30. Appropriate Agriculture International Co. L. 2015. http://www.koushu.co.jp/ AAI_E/NewsE/News05-4-E.pdf. Accessed 10 June 2015.

31. Beyaoui A, Chaari A, Ghouila H, Ali HM, Ben JH. New antioxidant bibenzyl derivative and isoflavonoid from the Tunisian Salsola tetrandra Folsk. Nat Prod Res. 2012;26:235-42

32. Khan KM, Maharvi GM, Abbaskhan A, Hayat S, Khan MTH, Makhmoor T, et al. Three Tyrosinase Inhibitors and Antioxidant Compounds from Salsola foetida. HCA. 2003;86:457-64.

33. Meltem Asan O, Mahmut E, Derya Onal D, Seher Karaman E, Mehtap T. Antimicrobial and antioxidant activity of various solvent extracts of Salsola stenoptera Wagenitz and Petrosimonia nigdeensis Aellen (Chenopodiaceae) plants. Chiang Mai J Sci. 2015:42(1):156-72.

34. Tundis R, Loizzo MR, Statti GA, Menichini F. Inhibitory effects on the digestive enzyme alpha-amylase of three Salsola species (Chenopodiaceae) in vitro. Pharmazie. 2007:62:473-5

35. Xiang Y, Li YB, Zhang J, Li P, Yao YZ. Studies on chemical constituents of Salsola collina. Zhongguo Zhong Yao Za Zhi. 2007;32:409-13.

36. Tackholm V: Students' Flora of Egypt. Egypt: Cairo University, Cairo; 1974

37. Boulos L. The Identity, Typification and Distribution of Salsola imbricata Forsskal: Studies in the Chenopodiaceae of Arabia. Kew Bull. 1991;46:137-40.

38. Hamed Al, Masullo M, Sheded MG, Mahalel UA, Tawfik MM, Perrone A, et al. Triterpene saponins from Salsola imbricata. Phytochem Lett. 2011;4:353-6.

39. Shehab NG, Abu-Gharbieh E. Phenolic Profiling and Evaluation of Contraceptive Effect of the Ethanolic Extract of Salsola imbricata Forssk. in Male Albino Rats. Evid Based Complement Alternat Med. 2014;2014:695291. 
40. Lorke D. A new approach to practical acute toxicity testing. Arch Toxicol. 1983;54:275-87.

41. Singleton VL, Rossi JA. Colorimetry of Total Phenolics with PhosphomolybdicPhosphotungstic Acid Reagents. Am J Enol Vitic. 1965;16:144-58.

42. Oktay M, Gulcin I, Kufrevioglu OI. Determination of in vitro antioxidant activity of fennel (Foeniculum vulgare) seed extracts. LWT Food Sci Technol. 2003;36:263-71.

43. Dewanto $\mathrm{V}, \mathrm{Wu}$ X, Adom KK, Liu RH. Thermal processing enhances the nutritional value of tomatoes by increasing total antioxidant activity. J Agric Food Chem. 2002;50:3010-4.

44. Goupy P, Hugues M, Boivin P, Amiot MJ. Antioxidant composition and activity of barley (Hordeum vulgare) and malt extracts and of isolated phenolic compounds. J Sci Food Agric. 1999;79:1625-34.

45. Mattila P, Astola J, Kumpulainen J. Determination of Flavonoids in Plant Material by HPLC with Diode-Array and Electro-Array Detections. J Agric Food Chem. 2000:48:5834-41.

46. Cheng Z, Moore J, Yu L. High-throughput relative DPPH radical scavenging capacity assay. J Agric Food Chem. 2006;54:7429-36.

47. Abu-Gharbieh E, Bayoumi FA, Ahmed NG. Alleviation of antioxidant defense system by ozonized olive oil in DNBS-induced colitis in rats. Mediators Inflamm. 2014;2014:967205.

48. Lowry OH, Rosebrough NJ, Farr AL, Randall RJ. Protein measurement with the Folin phenol reagent. J Biol Chem. 1951;193:265-75.

49. Webster D, Bignell AH, Attwood EC. An assessment of the suitability of bromocresol green for the determination of serum albumin. Clin Chim Acta. 1974;53:101-8

50. Johnston DE. Special considerations in interpreting liver function tests. Am Fam Physician. 1999:59:2223-30.

51. Brattin WJ, Glende Jr EA, Recknagel RO. Pathological mechanisms in carbon tetrachloride hepatotoxicity. J Free Radic Biol Med. 1985;1:27-38.

52. Muriel $P$, Escobar $Y$. Kupffer cells are responsible for liver cirrhosis induced by carbon tetrachloride. J Appl Toxicol. 2003;23:103-8.

53. Ohta Y, Kongo-Nishimura M, Matsura T, Yamada K, Kitagawa A, Kishikawa T. Melatonin prevents disruption of hepatic reactive oxygen species metabolism in rats treated with carbon tetrachloride. J Pineal Res. 2004;36:10-7.

54. Jensen JE, Stainberg SE, Freese P, Marino E. Liver function tests. J Digest Disord. 2004:6:1-3.

55. Ryan CJ, Aslam M, Courtney JM. Transference of hepatic coma to norma rats from galactosamine treated donors by reverse plasma exchange. Biomater Artif Cells Artif Organs. 1990;18:477-82.

56. Halliwell B. Free radicals and antioxidants: a personal view. Nutr Rev. 1994;52:253-65.

57. Sekher PA, Chan TS, O'Brien PJ, Rice-Evans CA. Flavonoid B-ring chemistry and antioxidant activity: fast reaction kinetics. Biochem Biophys Res Commun. 2001;282:1161-8.

58. Kim JW, Yang H, Cho N, Kim B, Kim YC, Sung SH. Hepatoprotective constituents of Firmiana simplex stem bark against ethanol insult to primary rat hepatocytes. Pharmacogn Mag. 2015;11:55-60.

59. Lucarini R, Bernardes WA, Tozatti MG, Filho A, Silva M, Momo C, et al. Hepatoprotective effect of Rosmarinus officinalis and rosmarinic acid on acetaminophen-induced liver damage. Emir J Food Agric. 2014;26:878-84.

60. Ahmad ST, Arjumand W, Nafees S, Seth A, Ali N, Rashid S, et al. Hesperidin alleviates acetaminophen induced toxicity in Wistar rats by abrogation of oxidative stress, apoptosis and inflammation. Toxicol Lett. 2012;208:149-61.

61. Wilmsen PK, Spada DS, Salvador M. Antioxidant activity of the flavonoid hesperidin in chemical and biological systems. J Agric Food Chem. 2005;53:4757-61.

62. Pradeep K, Park SH, Ko KC. Hesperidin a flavanoglycone protects against gamma-irradiation induced hepatocellular damage and oxidative stress in Sprague-Dawley rats. Eur J Pharmacol. 2008;587:273-80.

63. Zheng QS, Sun XL, Xu B, Li G, Song M. Mechanisms of apigenin-7-glucoside as a hepatoprotective agent. Biomed Environ Sci. 2005;18:65-70.

64. Sal'nikova SI, Dorogovoz SM, Slyshkov W, Guzhva NN. Hepatoprotective activity of analogs of cinnamic acid. Farmakol Toksikol. 1989;52:77-80.

65. Johnson IT, Gee JM, Price K, Curl C, Fenwick GR. Influence of saponins on gut permeability and active nutrient transport in vitro. J Nutr. 1986;116:2270-7.

66. Cheeke PR. Biological effects of feed and forage saponins and their impacts on animal production. Adv Exp Med Biol. 1996:405:377-85.
67. Xi M, Hai C, Tang H, Wen A, Chen H, Liu R, et al. Antioxidant and antiglycation properties of triterpenoid saponins from Aralia taibaiensis traditionally used for treating diabetes mellitus. Redox Rep. 2010;15:20-8

68. Ponou BK, Teponno RB, Ricciutelli M, Quassinti L, Bramucci M, Lupidi G, et al. Dimeric antioxidant and cytotoxic triterpenoid saponins from Terminalia ivorensis A. Chev Phytochemistry. 2010;71:2108-15.

\section{Submit your next manuscript to BioMed Central and take full advantage of:}

- Convenient online submission

- Thorough peer review

- No space constraints or color figure charges

- Immediate publication on acceptance

- Inclusion in PubMed, CAS, Scopus and Google Scholar

- Research which is freely available for redistribution 